\title{
Financial Services
}

\section{Providing Strategic Legal Guidance to the Global Financial Services Industry}

JUNE 5, 2018

For more information, contact:

Sarah R. Borders

+14045723596

sborders@kslaw.com

Christopher T. Buchanan

+17045032602

cbuchanan@kslaw.com

Jason P. Huff

+17045032559

ihuff@kslaw.com

Terry D. Novetsky

+12125562328

tnovetsky@kslaw.com

John C. Taylor

+442075517553

itaylor@kslaw.com

Michael L. Urschel

+12125562285

murschel@kslaw.com

King \& Spalding

Atlanta

1180 Peachtree Street, NE

Atlanta, GA 30309

Charlotte

300 S Tryon Street

Charlotte, NC 28202

New York

1185 Avenue of the Americas

New York, NY 10036

\section{Renewed Interest in Synthetic Leases - A Refresher and Changes Under the New (ASC 842) Lease Accounting Standard}

A synthetic lease is a financing technique structured to be an operating lease for the lessee's financial accounting purposes and a financing for U.S. federal tax purposes. Synthetic leases are most often used in acquisition or construction facilities for company headquarters or other real estate projects, corporate aircraft and large equipment, but the technique has wide application. They provide a method to finance the full cost of construction or acquisition at competitive rates without requesting funds from a corporate credit facility while permitting the lessee depreciation deductions.

Although this financing technique's popularity dipped years ago, we've experienced increasing synthetic leasing engagements and requests to assist with evaluating and implementing synthetic leasing as a new product offering. These developments are occurring even in the face of new financial accounting changes that once effective will affect the lessee's balance sheet treatment of leases, including synthetic leases. This alert provides a brief description of synthetic leases, their history, financial accounting changes and some advantages/disadvantages of this specialized type of lease.
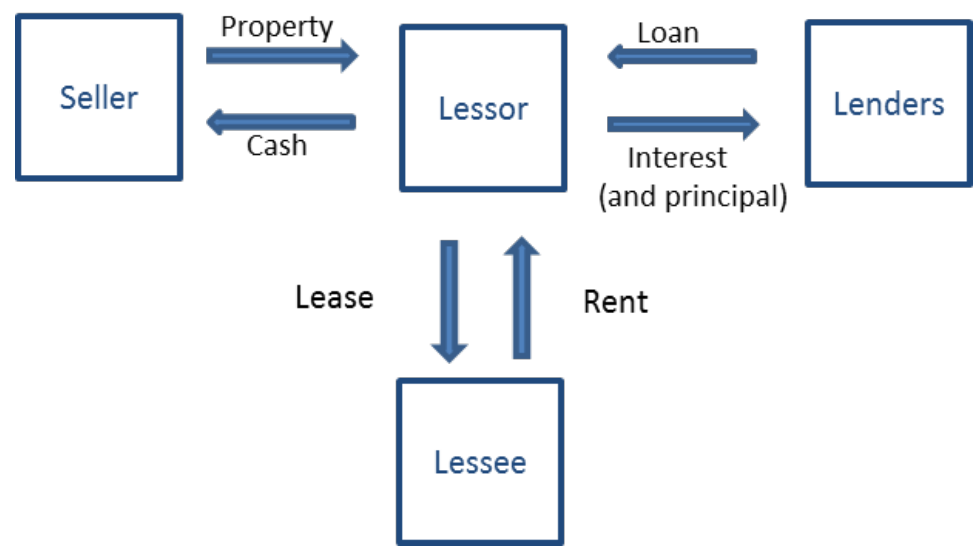


\section{THE STRUCTURE}

Traditional operating leases treat the lessor as the owner for both financial accounting and U.S. federal tax purposes, while a synthetic lease bifurcates the typical accounting and tax treatment. Unlike most operating leases where the lessor is treated as the tax owner for U.S. federal income tax purposes, in a synthetic lease, the lessee is treated as the owner, and therefore is entitled to depreciation deductions with respect to the property. Similarly, the lessee is also typically able to deduct the interest portion of the lease payments as interest expense for U.S. federal tax purposes.

The lessor is usually a bank or large finance company due to financial accounting changes that occurred in 2003 . The lessor is also the borrower under a loan facility that provides financing for $75 \%$ or more of the cost of the leased asset from banks or other finance companies. Lease payments by the lessee are sufficient to service the debt as well as the lessor's investment and generally include little or no amortization during the lease term. In a bankruptcy, a synthetic lease is treated as a secured loan from the lessor to the lessee.

\section{END OF TERM OPTIONS}

Synthetic leases are triple net leases (i.e., all expenses of operating the property are borne by the lessee) and at the end of the lease term, the lessee typically has the option to extend the lease term, return the property or purchase the property. If the lessee elects to return the property, then the lessor will market the property for sale to a third party; however, the lessee may be required to make a potentially substantial lease termination payment if the sale price is less than an agreed upon threshold. Such lease termination payments can be up to $65-80 \%$ of the initial cost of the property if the net sales proceeds are lower than expected. The lessor also bears some asset risk because the lessee is not required to pay the full amount of the property cost if the property is returned. Because the lessee often relies on the property and the lease termination payment can be substantial, the lessee usually extends the lease term or purchases the property. Of course, the lessee could opt to resell the property thereafter.

\section{A BRIEF HISTORY}

Synthetic leases were very popular with companies growing quickly that did not want to tie up capital in large asset acquisitions. Certain financial ratios, such as return on assets, were enhanced because the assets subject to a synthetic lease were not included on the lessee's balance sheet. This off balance sheet treatment became an issue in the press and became the target of public scrutiny. Around 2001, there were many articles about complex corporate off balance sheet finance and guaranty structures that obfuscated the capital structure; the criticism of off balance sheet structures expanded to include articles criticizing companies for synthetic leases. When off balance sheet structures became the target of negative press, interest in synthetic leases declined significantly as companies shied away from these structures.

In addition to the negative press, in 2003, the FASB implemented new guidance in FIN 46 Consolidation of Variable Interest Entities that disrupted the predominant structure of synthetic leases by significantly restricting the use of a special purpose entity with a single asset as the lessor. Essentially, FIN 46 provided that if the lessee is the primary beneficiary of a variable interest entity, such as a single-asset lessor, then the lessor entity must be consolidated by the lessee on its financial statements destroying the off balance sheet benefits of a synthetic lease. In response, financial institutions began providing multi-asset entities to serve as the lessor in most synthetic leases.

\section{OFF BALANCE SHEET TREATMENT - THEN AND NOW}

Unlike assets and liabilities in a loan transaction or a capital lease, operating lease (and synthetic lease) assets and liabilities do not appear on the lessee's balance sheet, although the payments flow through the income and cash flow statements. This off balance sheet treatment was appealing to companies in the past, even after agents and lenders in credit facilities revised their financial covenant calculations to expressly include synthetic leases as indebtedness. 
Ironically, the end of what was once considered a benefit of synthetic leasing - the off balance sheet treatment by the lessee - may be sparking renewed interest in the product. Like other operating leases, synthetic leases will be required to be included on the lessee's balance sheet upon implementation of ASC 842. With this change to the off balance sheet treatment for operating leases, ASC 842 will require the lessee to record a "Right-of-Use asset" on the balance sheet as well as a lease liability. This will eliminate one of the criticisms of synthetic leases and one benefit, but there are a number of other benefits that continue to make synthetic leases appealing.

\section{ADVANTAGES AND DISADVANTAGES}

Synthetic leases can provide very efficient financing. In a synthetic lease, the lessee is able to select the asset and may be able to make custom improvements or construct the facility to its specifications, subject to certain accounting limitations, and receive financing for the full cost of the asset - not just $70 \%$ or $80 \%$ of the cost. The financing rates for most facilities are competitive with the lessee's borrowing rate on its general working capital facility. In many cases the lessee's existing credit facility will not need to be amended since a synthetic lease facility is often permitted by the lessee's corporate credit facility, but these facilities will almost always include the synthetic lease as indebtedness in the calculation of financial covenants. As mentioned previously, the lessee is typically able to depreciate the asset for federal income tax purposes and has the ability to purchase the property at the end of the lease term for an agreed upon amount, which permits the lessee to realize any appreciation on the property. During the lease term, there is minimal amortization, which lowers the lessee's lease payments. As a result, the lessee must have strong credit quality to qualify for a synthetic lease. This is also a complex product, which means it is more expensive to put in place and to avoid consolidation onto the lessee's balance sheet, a substantive lessor is typically needed, which further limits the parties willing to serve in this capacity. As mentioned briefly above, there are also accounting changes in ASC 842 that will impact synthetic leases. First, upon implementation of ASC 842, which will commence with fiscal year 2019 for most public companies and the following year for private companies, there will be a Right-of-Use asset on the lessee's balance sheet and a lease liability. The lease liability will be discounted to present value for reporting purposes. The lessee accounting rules for determining whether a lease is an operating lease or a capital lease will be subject to additional interpretation since the bright-line tests with percentages will become guidelines. To allay concerns from these changes, at least one of the big 4 accounting firms has confirmed in their literature that they will not object to the use of the bright-line tests from ASC 840 to make this determination under the new lease standards of ASC 842.

The 2017 Tax Cuts and Jobs Act changed a number of key leasing/financing related provisions. The most significant in this context should be the introduction of $100 \%$ expensing for qualified tangible property with a recovery period of 20 years or less. This current year expensing applies to property placed in service after September 27, 2017 and before January 1,2023 , and for phased-down amounts (20\% annual reduction of the percentage) generally through 2026 . The recovery period for real estate assets exceeds 20 years and thus real estate assets do not qualify for expensing, but other associated tangible personal property may qualify. This $100 \%$ expensing opportunity may spur some taxpayers to seek synthetic lease treatment for qualifying assets so that, as the tax owner, the lessee may claim the full expensing. This benefit needs to be balanced against another new provision that limits the deduction for "business interest" for any taxable year to the sum of the taxpayer's "business interest income" and $30 \%$ of the taxpayer's "adjusted taxable income" for the taxable year. In general, adjusted taxable income is defined as EBITDA before 2022 and EBIT thereafter.

\section{CONCLUSIONS}

While synthetic leasing will not be as common as many other types of lease facilities, it does provide a good alternative for companies that are interested in a method to keep lease payments low during the lease term, depreciate the property for U.S. federal tax purposes and have the ability to acquire the property. Certain issues and considerations are beyond 
the scope of this brief alert; please contact us if you would like more information - whether as a lessee, lessor or party looking to add synthetic leasing to your finance offerings.

\section{ABOUT KING \& SPALDING}

Celebrating more than 130 years of service, King \& Spalding is an international law firm that represents a broad array of clients, including half of the Fortune Global 100, with 1,000 lawyers in 20 offices in the United States, Europe, the Middle East and Asia. The firm has handled matters in over 160 countries on six continents and is consistently recognized for the results it obtains, uncompromising commitment to quality, and dedication to under- standing the business and culture of its clients.

This alert provides a general summary of recent legal developments. It is not intended to be and should not be relied upon as legal advice. In some jurisdictions, this may be considered "Attorney Advertising."

$\begin{array}{lllll}\text { ABU DHABI } & \text { CHICAGO } & \text { HOUSTON } & \text { NEW YORK } & \text { SILICON VALLEY } \\ \text { ATLANTA } & \text { DUBAI } & \text { LONDON } & \text { PARIS } & \text { SINGAPORE } \\ \text { AUSTIN } & \text { FRANKFURT } & \text { LOS ANGELES } & \text { RIYADH } & \text { TOKYO } \\ \text { CHARLOTTE } & \text { GENEVA } & \text { MOSCOW } & \text { SAN FRANCISCO } & \text { WASHINGTON, D.C. }\end{array}$

